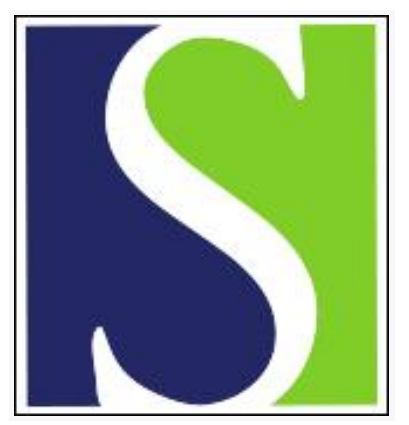

Scand J Work Environ Health 2011;37(2):129-135

https://doi.org/10.5271/sjweh.3074

Published online: 05 Aug 2010, Issue date: Mar 2011

No short-term respiratory effects among particle-exposed employees in the Stockholm subway

by Bigert C, Alderling M, Svartengren M, Plato N, Gustavsson P

Affiliation: Institute of Environmental Medicine, Karolinska Institutet, SE-171 76 Stockholm, Sweden. carolina.bigert@ki.se

Key terms: air pollution; employee; lung function; occupational exposure; particle exposúre; particle-exposed employee; particulate matter; respiratory effect; short-term respiratory effect; subway; Sweden; underground

This article in PubMed: www.ncbi.nlm.nih.gov/pubmed/20686740 


\title{
No short-term respiratory effects among particle-exposed employees in the Stockholm subway
}

\author{
by Carolina Bigert, MD, ${ }^{1}$ Magnus Alderling, MSc, ${ }^{2}$ Magnus Svartengren, MD, ${ }^{2}$ Nils Plato, PhD, ${ }^{1}$ \\ Per Gustavsson, MD ${ }^{1}$
}

\begin{abstract}
Bigert C, Alderling M, Svartengren M, Plato N, Gustavsson P. No short-term respiratory effects among particleexposed employees in the Stockholm subway. Scand J Work Environ Health. 2011;37(2):129-135. doi:10.5271/ sjweh.3074
\end{abstract}

Objective Exposure to traffic-related air pollution is associated with adverse respiratory effects, but it is not known whether the high exposure to particles prevailing in the subway system may affect the respiratory system. We investigated airway inflammation and lung function among particle-exposed subway employees.

Methods We studied 81 workers. All participants were non-smokers, aged 25-50 years. Three exposure groups were formed according to particulate matter (PM) levels obtained during an occupational hygienic investigation: 30 platform workers [average $\mathrm{PM}_{2.5} 63 \mu \mathrm{g} / \mathrm{m}^{3}$ and DataRAM (MIE Inc, Billerica, Waltham, MA, USA) $182 \mu \mathrm{g} /$ $\left.\mathrm{m}^{3}\right]$, 30 subway drivers $\left(19 \mu \mathrm{g} / \mathrm{m}^{3}\right.$ and $\left.33 \mu \mathrm{g} / \mathrm{m}^{3}\right)$, and 21 ticket sellers $\left(10 \mu \mathrm{g} / \mathrm{m}^{3}\right.$ and $\left.13 \mu \mathrm{g} / \mathrm{m}^{3}\right)$. We measured the fractional exhaled nitric oxide (FENO) of all workers before and after a workday. We also measured the peak expiratory flow $(\mathrm{PEF})$ and forced expiratory volume in one second $\left(\mathrm{FEV}_{1}\right)$ of platform workers and ticket sellers five times a day over two weeks. We calculated the arithmetic means of PEF and $\mathrm{FEV}_{1}$ during exposed and unexposed time for every individual.

Results There was no significant increase in FENO after work among platform workers, subway drivers or ticket sellers (the means of percentual individual change were $-7 \%,+2 \%$ and $-4 \%$ respectively). The averages of the ratios (exposed to unexposed time) of PEF and $\mathrm{FEV}_{1}$ were above 1.0 for both ticket sellers (1.016 and 1.002 respectively) and platform workers (1.022 and 1.005).

Conclusions Our observations do not indicate any short-term respiratory effects of particle exposure in the subway among the employees, with respect to airway inflammation or lung function.

Key terms air pollution; lung function; occupational exposure; particulate matter; Sweden; underground.

Epidemiologic studies have demonstrated associations between particles in urban air, mainly derived from traffic, and respiratory-associated morbidity and mortality (1-4) and cardiovascular disease $(3,5)$. Particulate matter (PM) pollution has been suggested to be the major contributor to these effects (6). A main hypothesis concerning the mechanisms involved is that inhaled particles deposited in the airway epithelium may cause inflammation in lower airways, systemic inflammation, and oxidative stress. Nitric oxide (NO) is endogenously produced when airways are inflamed. The fractional concentration of $\mathrm{NO}$ in exhaled breath (FENO) is a marker of airway inflammation and has been used to investigate the relationship between exposure to air pollutants and airway inflammation $(4,7-9)$. Exposure to wood smoke among healthy subjects increased alveolar NO three hours after exposure, but there was no difference in the effects of wood smoke versus clean air on FENO at an exhalation flow rate of $50 \mathrm{ml} / \mathrm{sec}$, thus indicating inflammation at the distal parts of the airways rather than the conducting airways (9). Among children with asthma, the FENO was associated with hourly averages of $\mathrm{PM}_{2.5}$ from 1 up to 10-12 hours after exposure (7). Short-term exposure to diesel traffic in a central London street induced reductions in the forced expiratory volume in one second $\left(\mathrm{FEV}_{1}\right)$ and forced vital capacity (FVC) and increased biomarkers of

1 Unit of Occupational Medicine, Institute of Environmental Medicine, Karolinska Institutet, Stockholm, Sweden.

2 Division of Occupational and Environmental Medicine, Department of Public Health Sciences, Karolinska Institutet, Stockholm, Sweden.

Correspondence to: Dr Carolina Bigert, Institute of Environmental Medicine, Karolinska Institutet, Norrbacka 4th Floor, SE-171 76 Stockholm, Sweden. [E-mail: carolina.bigert@ki.se] 
inflammation among people with asthma (10). Healthy persons exposed to road tunnel air pollution in Stockholm got airway inflammation, as reflected in broncheoalveolar lavage fluid and bronchial mucosal biopsies, but no reductions in $\mathrm{FEV}_{1}$ or FVC (11).

However, very little is known about the potential respiratory effects of exposure to particles in the subway system, another source of particulate air pollution. The subway particles contain a high proportion of iron and derive mainly from wheels, rails, and brakes. They are larger than particles generated by combustion engines, mainly in the size range of 1-10 microns (12-14). Transportation workers and commuters are mainly exposed at the underground platforms. Levels of particles with an aerodynamic diameter of $<10 \mu \mathrm{m}\left(\mathrm{PM}_{10}\right)$ measured on an underground platform in central Stockholm were on average $470 \mu \mathrm{g} / \mathrm{m}^{3}$, which is a factor five times higher than the corresponding values measured on one of the busiest city streets (15). Exposure to a subway environment for two hours did not induce reductions in lung function or changes in exhaled NO among healthy volunteers in Stockholm (16), but experimental data indicate that subway particles have marked inflammatory properties on the cell level $(12,17,18)$ and induce more oxidative stress than street-level particles $(18$, 19). Since high levels of particles have been reported in the subway system of Stockholm (15), as well as in several other cities in the world (20-23), and previous studies indicate inflammatory effects of these particles, we investigated the potential respiratory effects among particle-exposed employees in the subway.

\section{Methods}

\section{Study group}

The study group comprised 81 employees of the Stockholm subway. The participants were non-smoking men and women, aged $25-50$ years. All subjects had to be currently working. They all participated in an individual medical examination performed once for each person between November 2004 and March 2005. During the same time period, exposure measurements were performed for 44 of the participants, with the first day of exposure measurements usually occurring the same day as the medical examination. Three exposure groups were formed according to the level of exposure to subway particles. There were (i) 30 platform workers (cleaners and ticket collectors whose main working site was on the platforms) who had the highest exposure among the occupational groups studied, (ii) 30 intermediately exposed subway drivers, and (iii) 21 ticket sellers with low exposure (control group).

\section{Background characteristics}

At the medical examination in a room adjacent to their workplace, the participants were examined and interviewed about the state of their health and medication use. One physician and one laboratory assistant took part in all examinations. This individual medical examination was done in the morning, right before the start of a work shift, after at least two work-free days. All participants had previously fasted overnight due to the need for the collection of blood samples as part of the medical examination. The results from analyses of blood samples have been presented elsewhere (24). The examination included the recording of weight and height. At the same occasion and in the same room, the first measurements of FENO (all participants) and peak expiratory flow (PEF) and $\mathrm{FEV}_{1}$ (ticket sellers and platform workers) were recorded. After the medical examination, those who participated in the exposure measurements put on the personal sampling equipment. Individuals who had smoked on a regular basis any time before inclusion in the study were coded as ex-smokers. There was an equal distribution between the occupational groups with regard to the limited numbers of participants with asthma and limited use of inhaled anti-inflammatory medication. No one was on oral anti-inflammatory medication. Table 1 shows the background characteristics of the exposure groups and mean values of $\mathrm{FEV}_{1}$ registrations for two weeks.

\section{Information on particle exposure}

The exposure to particles [measured as $\mathrm{PM}_{2.5}$ and by DataRAM (MIE Inc, Billerica, MA, USA)] was investigated by personal sampling during two work shifts for 44 of the participants. More detailed information about the exposure measurements has been presented elsewhere (25). Each sampling shift was about eight hours. The first day of measurements usually occurred the same day as the medical examination and the subsequent day of measurements within the following 1-2 weeks.

To collect $\mathrm{PM}_{2.5}$, we used the cyclone GK2.05 (KTL) (BGI Incorporated, Waltham, MA, USA), with the flow rate $4 \mathrm{l} / \mathrm{min}$, measuring all particles in sizes $<2.5$ micrometer. The filters used were $37 \mathrm{~mm}$ Teflon filters weighed with a balance of sensitivity $0.001 \mathrm{mg}$ in a room with constant temperature $\left(20^{\circ} \mathrm{C}\right)$ and $50 \%$ relative humidity. Real time particle measurements were performed with the person-borne direct reading instrument DataRAM (type MIE pDR 1000) which is a light scattering instrument that uses a nefelometric method scanning particles in sizes $0.1-10$ micrometer. The average of every minute was recorded and stored in a built data logger. 
Table 1. Background characteristics of the exposure groups regarding gender, age, body mass index (BMI), previous smoking habits, asthma, inhalable anti-inflammatory medication, and forced expiratory volume in one second $\left(\mathrm{FEV}_{1}\right)$.

\begin{tabular}{|c|c|c|c|c|c|c|c|c|c|c|c|c|}
\hline & \multicolumn{4}{|c|}{ Ticket sellers $(\mathrm{N}=21)$} & \multicolumn{4}{|c|}{ Subway drivers $(\mathrm{N}=30)$} & \multicolumn{4}{|c|}{ Platform workers $(\mathrm{N}=30)$} \\
\hline & $\mathrm{N}$ & $\%$ & Mean & Range & N & $\%$ & Mean & Range & $\mathrm{N}$ & $\%$ & Mean & Range \\
\hline Gender (male) & 13 & 62 & & & 18 & 60 & & & 24 & 80 & & \\
\hline Age & & & & $25-50$ & & & 38 & $25-50$ & & & 40 & $25-50$ \\
\hline $\mathrm{BMI}$ & & & 25 & $19-35$ & & & 26 & $19-35$ & & & 28 & $20-38$ \\
\hline Ex-smoker & 6 & 29 & & & 18 & 60 & & & 6 & 20 & & \\
\hline Asthma & 2 & 9 & & & 2 & 7 & & & 3 & 10 & & \\
\hline Daily inhalable anti-inflammatory medication & 1 & 5 & & & 2 & 7 & & & 2 & 7 & & \\
\hline $\mathrm{FEV}_{1}(\mathrm{l} / \mathrm{sec})$ & & $80^{\mathrm{a}}$ & 3.12 & & & & & & & $81^{a}$ & 3.27 & \\
\hline
\end{tabular}

a Percent of predicted.

\section{Measurement of fractional exhaled nitric oxide}

On the same day as the medical examination, the FENO was investigated among all ticket sellers, subway drivers, and platform workers. The first measurement was done before the start of a work shift after at least two work-free days. The second measurement was taken the same day directly after the end of the work shift. All measurements were made in the same room (an office room with mechanical ventilation, adjacent to the work place) and with the same analyzer. The FENO was measured with the subject in a seated position using a NIOX chemiluminescence analyzer (Aerocrine AB, Stockholm, Sweden) during a single slow exhalation against an oral pressure of $5 \mathrm{~cm} \mathrm{H}_{2} \mathrm{O}$. Measurements were taken for 10 seconds aiming at an exhalation flow rate of $50 \mathrm{ml} / \mathrm{sec}$, according to guidelines established by the American Thoracic Society and European Respiratory Society (26). All measurements were taken threefold and the mean concentration (in parts per billion) was registered. The analyzer was calibrated once a week with a certified NO calibration gas.

\section{Measurement of peak expiratory flow and forced expiratory volume in one second}

Using a portable Piko-1 electronic PEF and $\mathrm{FEV}_{1}$ meter, (Medeca Pharma AB, Uppsala, Sweden) measurements were performed on all ticket sellers and platform workers, with the first registration on the same day as the medical examination and the FENOmeasurements. All subjects borrowed a Piko-1 meter and made five registrations a day for two weeks, both at work and at leisure time. All registrations were made threefold and the best value out of three was stored and used in the analysis. The Piko-1 meter registered PEF and $\mathrm{FEV}_{1}$. The subjects got detailed oral and written instructions for the registrations and also practiced how to handle the Piko-1 meter. Before the first measurement, we checked that their technique of measurement was adequate by using a stationary spirometer that gave values of $\mathrm{FVC}, \mathrm{FEV}_{1}, \mathrm{PEF}$ and the form of the curve. They received a form to register their working hours.

\section{Statistical methods}

To investigate whether the FENO was higher after a workday compared to the baseline value, we calculated the mean of percentual individual change for each group, with standard deviation (SD). We used a twosided t-test to analyze whether there was a significant percentage change. We also present the arithmetic mean of the FENO in parts per billion for each exposure group before and after work.

For PEF and $\mathrm{FEV}_{1}$, we compared exposed and unexposed time by calculating the mean of all PEF and $\mathrm{FEV}_{1}$ measurements at work and during leisure time for each individual. Secondly, we calculated an individual ratio between the mean value at work and leisure time. The arithmetic mean and SD of these individual ratios was calculated for each occupational group. The ratios were normally distributed. A two-sided t-test was performed to analyze whether the $\mathrm{PEF}$ and $\mathrm{FEV}_{1}$ ratios significantly differed from 1.0.

To investigate if there was a trend to a change in PEF or FEV 1 during the working week, we calculated the mean of all measurements for each of the first four days and used a regression analysis to investigate if there was a trend over time.

In addition, we analyzed whether there was a diurnal variation in PEF or FEV 1 . We calculated the arithmetic mean and SD of individual ratios between the mean value at daytime and mean value in morning and night, for all study subjects combined.

The Regional Ethics Committee in Stockholm, Sweden, evaluated and approved the study. All study subjects were included following informed consent. 


\section{Results}

The results from the exposure measurements are shown in table 2. The levels of $\mathrm{PM}_{2.5}$ for the platform workers were about six times higher than those of ticket sellers, and about twice as high among subway drivers, with an average $\mathrm{PM}_{2.5}$ of $63 \mu \mathrm{g} / \mathrm{m}^{3}$ for platform workers, $19 \mu \mathrm{g} / \mathrm{m}^{3}$ for subway drivers, and $10 \mu \mathrm{g} / \mathrm{m}^{3}$ for ticket sellers. The corresponding DataRAM levels were $182 \mu \mathrm{g} / \mathrm{m}^{3}, 33 \mu \mathrm{g} / \mathrm{m}^{3}$, and $13 \mu \mathrm{g} / \mathrm{m}^{3}$, respectively.

Table 2. Information on exposure to particles measured as particulate matter $\left(\mathrm{PM}_{25}\right)$ and by DataRAM by personal sampling during two work shifts for 44 workers in the Stockholm subway.

\begin{tabular}{|c|c|c|c|c|c|c|}
\hline & \multicolumn{2}{|c|}{$\begin{array}{l}\text { Ticket sellers } \\
\qquad(\mathrm{N}=8)\end{array}$} & \multicolumn{2}{|c|}{$\begin{array}{l}\text { Subway drivers } \\
\quad(N=13)\end{array}$} & \multicolumn{2}{|c|}{$\begin{array}{l}\text { Platform workers } \\
\qquad(\mathrm{N}=23)\end{array}$} \\
\hline & Mean & SD & Mean & SD & Mean & SD \\
\hline $\mathrm{PM}_{2.5}\left(\mu \mathrm{g} / \mathrm{m}^{3}\right)$ & 10 & 3 & 19 & 3 & 63 & 12 \\
\hline DataRAM $\left(\mu \mathrm{g} / \mathrm{m}^{3}\right)$ & 13 & 3 & 33 & 12 & 182 & 57 \\
\hline
\end{tabular}

Table 3. Findings of measurements of the fraction of exhaled nitric oxide (FENO) per exposure group, before and after work. The arithmetic mean of FENO in parts per billion ( $\mathrm{ppb})$, and mean of percentual individual change with standard deviation (SD).

\begin{tabular}{|c|c|c|c|c|c|c|}
\hline & \multicolumn{2}{|c|}{$\begin{array}{l}\text { Ticket sellers } \\
\quad(N=21)\end{array}$} & \multicolumn{2}{|c|}{$\begin{array}{l}\text { Subway drivers } \\
(N=30)\end{array}$} & \multicolumn{2}{|c|}{$\begin{array}{l}\text { Platform workers } \\
\qquad(\mathrm{N}=30)\end{array}$} \\
\hline & Mean & $S D$ & Mean & SD & Mean & SD \\
\hline FENO before work & $21.8^{\mathrm{a}}$ & 17.2 & $22.3^{a}$ & 15.5 & $22.1^{\text {a }}$ & 18.0 \\
\hline FENO after work & $22.2^{\mathrm{a}}$ & 20.3 & $22.1^{\mathrm{a}}$ & 14.4 & $21.2^{a}$ & 21.0 \\
\hline $\begin{array}{l}\text { Percentual } \\
\text { individual change } \\
\text { in FENO }\end{array}$ & $-4 \%$ & $25 \%$ & $+2 \%$ & $21 \%$ & $-7 \%$ & $18 \%$ \\
\hline
\end{tabular}

a In group.

Table 4. Findings of the mean of Piko-1 meter-registered peak expiratory flow (PEF) and forced expiratory volume in one second (FEV $)_{1}$ ratios (ratio between work and leisure time) for each occupational group (based on the mean of individual ratios) during a two-week period and standard deviation (SD). P-values are for comparisons between the mean ratio for each group and the ratio 1.0.

\begin{tabular}{|c|c|c|c|c|c|c|}
\hline \multirow[t]{2}{*}{ Risk marker } & \multicolumn{3}{|c|}{ Ticket sellers $(\mathrm{N}=21)$} & \multicolumn{3}{|c|}{ Platform workers $(\mathrm{N}=30)$} \\
\hline & $\begin{array}{c}\text { Mean of } \\
\text { ratios }\end{array}$ & SD & P-value & $\begin{array}{c}\text { Mean of } \\
\text { ratios }\end{array}$ & SD & P-value \\
\hline PEF ratio & 1.016 & 0.039 & 0.074 & 1.022 & 0.048 & $0.020^{a}$ \\
\hline $\mathrm{FEV}_{1}$ ratio & 1.002 & 0.066 & 0.914 & 1.005 & 0.040 & 0.524 \\
\hline
\end{tabular}

a P-value $<0.05$
Table 3 shows findings from measurements of FENO for ticket sellers, subway drivers, and platform workers before and after work. There was no significant increase in the mean FENO after a workday, compared to the baseline value, in any of the exposure groups. The mean of percentual individual change in FENO was $-4 \%$ among ticket sellers, $+2 \%$ among subway drivers and $-7 \%$ (significant) among platform workers.

The mean PEF and $\mathrm{FEV}_{1}$ ratios were above 1.0 for both ticket sellers and platform workers, thus indicating better airflow function during work (table 3). Among the platform workers, the PEF ratio significantly differed from $1.0(\mathrm{P}=0.020)$.

There was no significant trend over time in PEF or $\mathrm{FEV}_{1}$ during the working week. For PEF, the mean value of exposed and unexposed measures combined were $472,473,490$, and $4761 / \mathrm{min}$ respectively for days $1-4$ ( $\mathrm{P}=0.666$ for the trend) among ticket sellers and 446 , 451,453 , and $4581 / \mathrm{min}$ respectively $(\mathrm{P}=0.346$ for the trend) among platform workers. For $\mathrm{FEV}_{1}$, the mean values were $3.29,3.20,3.31$, and $3.23 \mathrm{l} / \mathrm{sec}$ respectively for days $1-4(\mathrm{P}=0.875$ for the trend) among ticket sellers and $3.33,3.25,3.25$, and $3.25 \mathrm{l} / \mathrm{sec}$ respectively $(\mathrm{P}=0.8752$ for the trend) among platform workers.

When diurnal variation in PEF or $\mathrm{FEV}_{1}$ was analyzed using all unexposed measurements during the two-week period, we found no tendency towards better values at daytime compared to morning and night.

\section{Discussion}

There were no signs of acute airway inflammation among subway drivers or platform workers who were exposed to particles in the Stockholm subway. Nor were there any signs of negative effects on lung function during work. On the contrary, the comparison between exposed and unexposed time for PEF and $\mathrm{FEV}_{1}$ indicated better airflow during work. The reason for the general tendency of better airflow at work is unclear. It is notable that this tendency was significant only for PEF among platform workers but not for $\mathrm{FEV}_{1}$, which is a more robust measure than PEF. It is possible that some parameter in the work situation trigger the individuals to make a better effort in the measurement situation compared to during leisure time. Diurnal variation is also a possible explanation $(27,28)$, but additional analyses including only the measurements during leisure time did not confirm this hypothesis. Furthermore, we found no significant trend over time in $\mathrm{PEF}$ or $\mathrm{FEV}_{1}$ during the working week.

The FENO measurements indicated no inflammation after work. It is possible that the period of two days off duty before measuring the baseline value for 
the FENO was insufficient to reach baseline, leading to a reduced possibility to detect acute changes. Other potential explanations include the possibility of diurnal variation, which may mask a negative influence of the workplace exposure. A study among 20 asthmatic and 6 healthy children in Germany suggested a diurnal rhythm of FENO in both groups, with a peak in the early morning (29) while two other studies did not report a diurnal pattern $(30,31)$. It is also possible that the FENO measurements were registered too early after the exposure to register an effect, since the second FENO registration was done directly after the end of the work shift. In a study on exposure to wood smoke (four hours exposure), the effect on alveolar NO was not directly noticeable but only three hours later (9) and, among children with asthma, there was a lag time from 1 up to 10-12 hours for the association between FENO and hourly averages of $\mathrm{PM}_{2.5}$ (7). However, in our study there was not even a tendency towards increased FENO levels after exposure for eight hours for the occupational group with the highest exposure. On the other hand, the exposure levels in the highest exposed group in our study were considerably lower than in the study on exposure to wood smoke where the mass concentrations of fine particles were $240-280 \mu \mathrm{g} / \mathrm{m}^{3}$. Also, FENO has been shown to be an airway-specific marker of predominantly eosinophilic inflammation associated with asthma (32, 33). However, in the occupational setting it has been shown that there are a substantial proportion of subjects with occupational asthma without eosinophilia (34). The lack of effect on FENO levels in the present study could be a result of the limitations of the FENO technique as a marker for non-eosinophilic airway inflammation. For measurements of FENO, different flow rates have been used to determine the relative contribution of the bronchi and alveolar regions to FENO production (33). Since FENO - at a flow rate of $50 \mathrm{ml} / \mathrm{sec}$ - is supposed to indicate inflammation at the conducting airways (9), we may have missed an inflammatory response at the distal parts of the airways.

Normal values (upper limits) of FENO for adult non-smokers range between 24.0-54.0 parts per billion, depending on age and height (35). Levels of FENO are elevated among subjects with asthma symptoms and are positively related to height and age, while smoking and the use of inhaled corticosteroids have been associated with decreased FENO levels (36). Since the comparison in our study was done for FENO values before and after work for each individual, most of these parameters would not influence the results. No participant was smoking and very few were on inhalable anti-inflammatory medication. Intake of nitrate rich food has been shown to increase levels of FENO (37). When FENO before work was registered, the participants had been fasting over night, but food intake was allowed during the work-day and subsequently the FENO after work could have been affected by intake of food. However, this would not explain the lack of increased levels after work.

The classification into exposure groups was confirmed by personal exposure measurements for about half of the participants. Therefore, the risk of misclassification of exposure is low. The contrast between the highest and lowest exposed workers was high: for $\mathrm{PM}_{2.5}$, the exposure levels were about 6 times higher for platform workers $\left(63 \mu \mathrm{g} / \mathrm{m}^{3}\right)$ compared to the control group ticket sellers $\left(10 \mu \mathrm{g} / \mathrm{m}^{3}\right.$ ), and for DataRAM (nefelometric $\left.\mathrm{PM}_{0.1-10}\right)$ about 14 times higher $\left(182 \mu \mathrm{g} / \mathrm{m}^{3}\right.$ and $13 \mu \mathrm{g} / \mathrm{m}^{3}$, respectively) (25). The control group had an exposure to $\mathrm{PM}_{2.5}$ that was in line with the annual average background levels during daytime above roof across the greater Stockholm area. However, it is possible that the particle levels in the Stockholm subway are too low to induce airway inflammation or airway obstruction among healthy individuals. Many of the studies showing an association between combustion-generated particle exposure and respiratory effects have been performed on subjects with asthma. Particles formed in the subway also differ in size and composition from combustionrelated air pollution particulates which might be an explanation for the lack of effect, even though experimental studies indicate inflammatory effects on the cell level of subway particles $(12,17,18)$. The source of particulate air pollution in the subway is mainly from mechanical wear of wheels, rails, and brakes resulting in relatively large particles, which is typical for particles generated by mechanical wear, with a high content of metals, mainly iron, and with properties that considerably differ from those of combustion-generated air pollution. The number concentration of ultra-fine particles and nitrogen oxides are lower in the subway compared to road environments where particles and gases are emitted from gasoline and diesel engines.

Our negative findings are supported by a recent study in Stockholm with 20 healthy volunteers who were exposed to a subway environment for two hours (mean levels of $\mathrm{PM}_{2.5}$ and $\mathrm{PM}_{10}$ were $77 \mu \mathrm{g} / \mathrm{m}^{3}$ and $242 \mu \mathrm{g} / \mathrm{m}^{3}$, respectively) and an office environment (16). No significant changes between subway and office environment were observed in regard to $\mathrm{VC}, \mathrm{FVC}, \mathrm{FEV}_{1}$, PEF or exhaled NO, and no signs of cellular response in the lower airways assessed by bronchoscopy were found after exposure, regardless if cells were retrieved from peripheral or central airways. In an earlier study by the same research group using the same study design, the exposure to particles derived from city traffic (two hours exposure to air pollution in a road tunnel) increased the amount of inflammatory cells in broncheoalveolar lavage fluid of healthy individuals but no significant changes in lung function ( $\mathrm{VC}, \mathrm{FVC}$ and $\mathrm{FEV}_{1}$ ) occurred 
as a result of exposure (11). Since the exposure levels regarding $\mathrm{PM}_{2.5}$ and $\mathrm{PM}_{10}$ from city traffic were in the same levels (median concentrations of $\mathrm{PM}_{2.5}$ and $\mathrm{PM}_{10}$ were $64 \mu \mathrm{g} / \mathrm{m}^{3}$ and $176 \mu \mathrm{g} / \mathrm{m}^{3}$, respectively) as in the study among volunteers in the subway environment one could have expected signs of cellular inflammatory response in the lower airways after exposure to the subway environment as well. The lack of effect may be due to the differences in particle characteristics between the subway and road tunnel environments. In our study, the highest exposed group platform workers had similar exposure levels (mean levels of $\mathrm{PM}_{2.5}$ and $\mathrm{PM}_{0.1-10}$ were $63 \mu \mathrm{g} / \mathrm{m}^{3}$ and $182 \mu \mathrm{g} / \mathrm{m}^{3}$, respectively) as in the two aforementioned studies, but the exposure time was longer, 8 as opposed to 2 hours. In a previous investigation among the same study group of employees in the Stockholm subway, we found elevated plasma concentrations of the inflammatory marker PAI-1 and a tendency to elevated plasma concentrations of hs-CRP among platform workers, relative to employees with low exposure, but the differences observed could not definitely be linked to particle exposure as such, and we found no short-term effects of particle exposure on blood markers of inflammation and coagulation (24). These results are in accordance with the absence of short-term effects on airway inflammation in the present study. The participants in the occupational groups studied were mainly in good health and few had asthma. The results might have been different if we would have had the possibility to include only asthmatics.

A strength of the study is the personal measurements that showed a high exposure to airborne subway particles for platform workers relative to the control group and the background levels of particles. Sampling time of FENO and the choice of method for studying airway inflammation could have affected the outcome, although the method used is well established. The study could exclude a decrease in the ratio of $\mathrm{FEV}_{1}$ during work and leisure time with $1.2 \%$ or more with $95 \%$ certainty, and similarly a reduction in the PEF ratio with $1.5 \%$ and a change in FENO with 5\%, with $95 \%$ certainty.

In conclusion, we found no indication of short-term respiratory effects of particle exposure in the subway system among the employees, concerning negative effects on lung function or airway inflammation. However, we cannot rule out the effects of long-term exposure.

\section{Acknowledgements}

We thank Stina Gustavsson at the Institute of Environmental Medicine, Karolinska Institutet, Stockholm, who participated in the examinations. We thank the managers and employees at Connex Sverige AB in Stockholm for their contribution to the study. The Swedish Council for Working Life and Social Research study financially supported this study (grant number 2004-0276).

\section{References}

1. Janssen NA, Brunekreef B, van Vliet P, Aarts F, Meliefste $\mathrm{K}$, Harssema $\mathrm{H}$, et al. The relationship between air pollution from heavy traffic and allergic sensitization, bronchial hyperresponsiveness, and respiratory symptoms in Dutch school-children. Environ Health Perspect. 2003;111:1512-8.

2. Goldsmith CA, Kobzik L. Particulate air pollution and asthma: a review of epidemiological and biological studies. Rev Environ Health. 1999;14:121-34.

3. Brunekreef B, Beelen R, Hoek G, Schouten L, BauschGoldbohm S, Fischer P, et al. Effects of long-term exposure to traffic-related air pollution on respiratory and cardiovascular mortality in the Netherlands: the NLCS-study. Res Rep Health Eff Inst. 2009;(139):5-89.

4. Liu L, Poon R, Chen L, Frescura AM, Montuschi P, Ciabattoni $\mathrm{G}$, et al. Acute effects of air pollution on pulmonary function, airway inflammation, and oxidative stress in asthmatic children. Environ Health Perspect. 2009;117(4):668-74.

5. Seaton A, MacNee W, Donaldson K, Godden D. Particulate air pollution and acute health effects. Lancet. 1995;345(8943):176-8.

6. Bernstein JA, Alexis N, Barnes C, Bernstein IL, Bernstein JA, Nel A, et al. Health effects of air pollution. J Allergy Clin Immunol. 2004;114:1116-23.

7. Mar TF, Jansen K, Shepherd K, Lumley T, Larson TV, Koenig JQ. Exhaled nitric oxide in children with asthma and shortterm PM2.5 exposure in Seattle. Environ Health Perspect. 2005;113(12):1791-4.

8. Delfino RJ, Staimer N, Gillen D, Tjoa T, Sioutas C, Fung $\mathrm{K}$, et al. Personal and ambient air pollution is associated with increased exhaled nitric oxide in children with asthma. Environ Health Perspect. 2006;114(11):1736-43.

9. Barregard L, Sällsten G, Andersson L, Almstrand AC, Gustafson P, Andersson M, et al. Experimental exposure to wood smoke: effects on airway inflammation and oxidative stress. Occup Environ Med. 2008;65(5):319-24.

10. McCreanor J, Cullinan P, Nieuwenhuijsen MJ, Stewart-Evans J, Malliarou E, Jarup L, et al. Respiratory effects of exposure to diesel traffic in persons with asthma. N Engl $\mathrm{J}$ Med. 2007;357:2348-58.

11. Larsson BM, Sehlstedt M, Grunewald J, Sköld CM, Lundin A, Blomberg A, et al. Road tunnel air pollution induces bronchoalveolar inflammation in healthy subjects. Eur Respir J. 2007;29:699-705.

12. Seaton A, Cherrie J, Dennekamp M, Donaldson K, Hurley JF, Tran CL. The London Underground: dust and hazards to health. Occup Environ Med. 2005;62(6):355-62.

13. Hurley F, Cherrie J, Donaldsson K, Seaton A, Tran L. 
Assessment of health effects of long-term occupational exposure to tunnel dust in the London underground. Aberdeen (United Kingdom): Institute of Occupational Medicine, University of Aberdeen; 2003. Research Report TM/03/02.

14. Johansson C. Källor till partiklar i Stockholms tunnelbana [Particle sources in the Stockholm subway]. Stockholm: SLBanalys; 2005. Report 6.

15. Johansson C, Johansson P-A. Particulate matter in the underground of Stockholm. Atmos Environ. 2003;37:3-9.

16. Klepczynska Nyström A, Svartengren M, Grunewald J, Pousette C, Rödin I, Lundin A, et al. Health effects of a subway environment in healthy volunteers. Eur Respir J 2010;36(2):240-8.

17. Lindbom J, Gustafsson M, Blomqvist G, Dahl A, Gudmundsson A, Swietlicki E, et al. Exposure to wear particles generated from studded tires and pavement induces inflammatory cytokine release from human macrophages. Chem Res Toxicol. 2006;19(4):521-30.

18. Karlsson HL, Ljungman AG, Lindbom J, Moller L. Comparison of genotoxic and inflammatory effects of particles generated by wood combustion, a road simulator and collected from street and subway. Toxicol Lett. 2006;165(3):203-11.

19. Karlsson HL, Nilsson L, Moller L. Subway particles are more genotoxic than street particles and induce oxidative stress in cultured human lung cells. Chem Res Toxicol. 2005;18(1):19-23.

20. Adams HS, Nieuwenhuijsen MJ, Colvile RN, McMullen MA, Khandelwal P. Fine particle (PM2.5) personal exposure levels in transport microenvironments, London, UK. Sci Total Environ. 2001;279(1-3):29-44.

21. Seaton A, Cherrie J, Dennekamp M, Donaldson K, Hurley JF, Tran CL. The London underground: dust and hazards to health. Occup Environ Med. 2005;62(6):355-62.

22. Chillrud SN, Grass D, Ross JM, Coulibaly D, Slavkovich V, Epstein D, et al. Steel dust in the New York City subway system as a source of manganese, chromium, and iron exposures for transit workers. J Urban Health. 2005;82(1):3342 .

23. Ripanucci G, Grana M, Vicentini L, Magrini A, Bergamaschi A. Dust in the underground railway tunnels of an Italian town. J Occup Environ Hyg. 2006;3(1):16-25.

24. Bigert C, Alderling M, Svartengren M, Plato N, de Faire U, Gustavsson P. Blood markers of inflammation and coagulation and exposure to airborne particles in employees in the Stockholm underground. Occup Environ Med. 2008;65(10):655-8.

25. Plato N, Bigert C, Larsson BM, Svartengren M, Gustavsson P. Luftföroreningar i Stockholms tunnelbana: exponering för partiklar och kvävedioxid bland tunnelbanepersonal
[Particulate matter in the Stockholm subway: exposure to particles and nitrogen dioxide among subway staff]. Stockholm: Department of Occupational and Environmental Health, Stockholm Centre for Public Health; 2006. Internal Report 2006:2.

26. American Thoracic Society. ATS/ERS recommendations for standardized procedures for the online and offline measurement of exhaled lower respiratory nitric oxide and nasal nitric oxide, 2005. Am J Respir Crit Care Med. 2005;171(8):912-30.

27. Hetzel MR, Clark TJ. Comparison of normal and asthmatic circadian rhythms in peak expiratory flow rate. Thorax. 1980;35(10):732-8

28. Troyanov S, Ghezzo H, Cartier A, Malo JL. Comparison of circadian variations using FEV1 and peak expiratory flow rates among normal and asthmatic subjects. Thorax 1994;49(8):775-80

29. Mattes J, Storm van's Gravesande K, Moeller C, Moseler M, Brandis M, Kuehr J. Circadian variation of exhaled nitric oxide and urinary eosinophil protein $\mathrm{X}$ in asthmatic and healthy children. Pediatr Res. 2002;51(2):190-4.

30. Ten Hacken NH, van der Vaart H, van der Mark TW, Koëter GH, Postma DS. Exhaled nitric oxide is higher both at day and night in subjects with nocturnal asthma. Am J Respir Crit Care Med. 1998;158(3):902-7.

31. Georges G, Bartelson BB, Martin RJ, Silkoff PE. Circadian variation in exhaled nitric oxide in nocturnal asthma. J Asthma. 1999;36(5):467-73.

32. Kharitonov SA, Barnes PJ. Exhaled biomarkers. Chest. 2006;130(5):1541-6.

33. Payne DN. Nitric oxide in allergic airway inflammation. Curr Opin Allergy Clin Immunol. 2003;3(2):133-7.

34. Burge PS. Recent developments in occupational asthma. Swiss Med Wkly. 2010;140(9-10):128-32. Epub ahead of print.

35. Olin AC, Bake B, Torén K. Fraction of exhaled nitric oxide at $50 \mathrm{~mL} / \mathrm{s}$ : reference values for adult lifelong never-smokers. Chest. 2007;131(6):1852-6.

36. Olin AC, Rosengren A, Thelle DS, Lissner L, Bake B, Torén $\mathrm{K}$. Height, age, and atopy are associated with fraction of exhaled nitric oxide in a large adult general population sample. Chest. 2006;130:1319-25.

37. Olin AC, Aldenbratt A, Ekman A, Ljungkvist G, Jungersten $\mathrm{L}$, Alving $\mathrm{K}$, et al. Increased nitric oxide in exhaled air after intake of a nitrate-rich meal. Respir Med. 2001;95(2):153-8.

Received for publication: 22 December 2009 